\title{
Prolactin-induced termination of obligate diapause of mink (Mustela vison) blastocysts in vitro and subsequent establishment of embryonic stem-like cells
}

\author{
I. A. Polejaeva ${ }^{1}$, W. A. Reed ${ }^{1}$, T. D. Bunch ${ }^{1}$, L. C. Ellis ${ }^{2}$ and \\ K. L. White ${ }^{1 *}$ \\ ${ }^{1}$ Department of Animal, Dairy and Veterinary Sciences and ${ }^{2}$ Department of Biology, Biotechnology \\ Centre, Utah State University, Logan, UT 84322-4700, USA
}

\begin{abstract}
The mink reproductive cycle includes an obligatory period of embryonic diapause and delayed implantation, which continues in vitro and reduces the efficiency of embryonic stem (ES) cell establishment. Blastocysts recovered on day 7 and on days 13-16 after final mating were cultured in Dulbecco's modified Eagle's medium (DMEM) supplemented with various concentrations of prolactin to determine optimal conditions for embryo attachment and subsequent establishment of embryonic stem cells. Five treatments were applied to both ages of blastocyst: A, DMEM control $(n=16) ; \mathrm{B}, \mathrm{DMEM}+5 \mu \mathrm{g}$ prolactin $\mathrm{ml}^{-1}$ after 10 days initial culture in DMEM alone $(n=17)$; after 1 day of initial culture: C, DMEM + $10 \mathrm{ng}$ prolactin $\mathrm{ml}^{-1}(n=17)$; D, DMEM $+1 \mu \mathrm{g}$ prolactin $\mathrm{ml}^{-1}(n=19)$; and E, DMEM $+5 \mu \mathrm{g}$ prolactin $\mathrm{ml}^{-1}(n=17)$. Prolactin terminated diapause of day $13-16$ blastocysts at all concentrations tested. The maximum attachment of embryos in vitro and subsequent production of ES-like cells occurred in medium supplemented with $5 \mu \mathrm{g}$ prolactin $\mathrm{ml}^{-1}$. Prolactin did not affect attachment rates for day 7 blastocysts when $5 \mu \mathrm{g}$ prolactin $\mathrm{ml}^{-1}$ was added, but prolactin at concentrations of $1 \mu \mathrm{g} \mathrm{ml}^{-1}$ and $5 \mu \mathrm{g} \mathrm{ml}^{-1}$ when added on day I of culture enhanced ES-like cell line establishment. Two principal cell types were observed in the colonies: small stem cells and trophoblast-like cells with large areas of cytoplasm. The morphological evaluation of mink ES-like cell colonies was confirmed by cytochemical staining for alkaline phosphatase. Mink embryonic stem-like cells were found to stain positive for alkaline phosphatase. Alkaline phosphatase activity was lost upon cellular differentiation.
\end{abstract}

\section{Introduction}

Mink (Mustela vison) are seasonal breeders with fertility linked to the photoperiod just before the spring equinox. In addition, they are induced ovulators with the ability to ovulate a second wave of follicles by mating 10 days after the first ovulation. Embryos resulting from the first wave survive by entering an obligatory period of diapause and delayed implantation. Reactivation of the embryos occurs within the first week following the equinox. Blastocysts enter the uterus on days 5-6 after mating and then enter diapause. Diapause normally persists for 15 to 25 days but can be shortened (to 5 days) or prolonged (up to 55 days) by manipulation of the photoperiod (Hansson, 1947; Murphy and James, 1974; Martinet et al., 1981). True pregnancy, from implantation to parturition, lasts for about 30 days. The mechanism by which diapause is terminated in utero is poorly understood, but considerable evidence indicates that prolactin is a major component of the luteotrophic complex that terminates embryonic diapause in

*Correspondence. mink (Papke et al., 1980). Daily injection of prolactin beginning on day 7 after mating is followed by a rapid increase in plasma concentrations of progesterone 10 days earlier in treated than in untreated females (Martinet et al., 1981). Prolactin-treated females whelped 7 days earlier than control animals. Polejaeva et al. (1995) observed that day 14 blastocysts, with the zonae pellucidae removed, remained in suspension in vitro for the 10 days of the experiment and no embryonic stem (ES)-like cell colonies formed. In the study reported here we tested the hypothesis that prolactin acts directly on mink embryos to induce termination of diapause and subsequently increases the establishment of mink ES-like cell lines.

The production of animals derived from cultured ES cells by breeding chimaeras has enormous potential for genetic manipulation (Wilmut et al., 1991; Koller and Smithies, 1992; Zhou et al., 1993). ES-like cells have been isolated from different species; however, the creation of animal models with homologous recombination in ES cells from mammalian species other than the mouse has not been successful. One of the very important aspects of ES cell transgenic technologies is the potential to increase disease resistance by introducing specific 
genes into domestic animals. Potential areas of investigation include resistance to (1) parasitic organisms, (2) viral or bacterial organisms and (3) genetic diseases (Wheeler et al., 1995). An example of a disease that causes substantial economic loss to the fur industry is Aleutian disease. Aleutian disease of mink was first described by Hartsough and Gorham (1956). The causative agent, Aleutian disease virus, has been characterized as an autonomous parvovirus (Bloom et al., 1980). Aleutian disease may be targeted by ES cell methodologies. Genetic improvement leading to disease resistance may reduce significantly the economic impact of diseases that have been estimated to account for 10-20\% of total production overheads (Muller and Brem, 1991). By working with species other than the mouse, it should be possible to transfer ES cell technology to other mammals.

A major problem with developing ES cell technology is the identification of pluripotent cells as they begin to establish and grow in vitro. Detection of alkaline phosphatase activity is frequently used as a marker for undifferentiated mouse embryonic carcinoma (EC) and ES cells (Nicolas et al., 1976; Wobus et al., 1984), human EC cells (Benham et al., 1984), and ICM (inner cell mass) and epiblast cells of the earliest developmental stages of mouse embryos (Johnson et al., 1977). Usually, expression of alkaline phosphatase is decreased or completely lost upon cellular differentiation (Koopman and Cotton, 1984; Pease et al., 1990). Recently, alkaline phosphatase activity has been identified as a specific and convenient marker for undifferentiated pig and sheep epiblast cells (Talbot et al., 1993). No information has been published concerning alkaline phosphatase activity in mink ES-like cells. Alkaline phosphatase activity may also provide a convenient marker for undifferentiated mink embryo-derived cells as it has in other species. Primary and long-term cultures of ES-like cell lines derived from mink blastocysts were evaluated for alkaline phosphatase activity in this study.

\section{Materials and Methods}

\section{Animals}

Adult demi (wild-type) mink (Mustela vison) (body mass 0.96-1.4 kg) were mated three times between 4 and 9 March and were housed on local commercial farms in Cache Valley, Utah. The animals were housed in open sided sheds exposed to natural lighting and temperature. Water and commercial feed prepared by the Fur Farmers Agricultural Co-operative, Logan, Utah were provided ad libitum.

\section{Embryos and culture conditions}

Embryo age was calculated from the day of last mating (day o) before the collection day. Eighty-six were collected. Approximately half of the embryos (41) were recovered on days 5 and 7 after the final mating. Early embryos (8-cell, 16-cell and morulae) from day 5-7 donors were transferred into $30 \mu \mathrm{ml}$ drops (up to 10 embryos per drop) of CR2 medium (Wilkinson et al., 1996) and cultured to the blastocyst stage; early blastocysts from these donors were placed in DMEM culture (see below). The other embryos (45) were flushed from uteri on days 13-16. Pronase (Sigma, St Louis, MO) was used to remove the zonae pellucidae from embryos and all blastocysts were randomly allocated to treatments that consisted of the culture of individual embryos in Dulbecco's modified Eagle's medium (DMEM; HyClone, Logan, UT) supplemented with 10\% FBS (fetal bovine serum, HyClone), $0.1 \mathrm{mmol}$ B-mercaptoethanol $1^{-1}$ (Mallinckrodt, McGaw Park, IL), $0.1 \mathrm{mmol}$ ES cell qualified MEM non-essential amino acids $1^{-1}$ (Life Technologies, Grand Island, NY). Penicillin (Life Technologies) and streptomycin (Sigma) were included in the medium to control bacterial contamination, at final concentrations of $50 \mathrm{iu} \mathrm{ml} \mathrm{ml}^{-1}$ and $50 \mu \mathrm{g} \mathrm{ml} \mathrm{m}^{-1}$, respectively. Embryos were transferred into four-well culture dishes (Nunc, Neperville, IL) onto feeder layers of mouse primary embryonic fibroblasts. The mouse primary embryonic fibroblasts were established from 14-day-old mouse fetuses. The mitotic activity of the fibroblasts was blocked by an incubation for $2 \mathrm{~h}$ in medium containing $10 \mu \mathrm{g}$ mitomycin $\mathrm{C} \mathrm{ml}^{-1}$ (Sigma). Five treatment groups were established for both ages of blastocysts: A: DMEM - control ( $n=16$ embryos); B: DMEM plus $5 \mu \mathrm{g}$ prolactin $\mathrm{ml}^{-1}$ after 10 days initial culture in DMEM alone ( $n=17$ embryos); C, DMEM + $10 \mathrm{ng}$ prolactin $\mathrm{ml}^{-1}(n=17)$; $\mathrm{D}, \mathrm{DMEM}+1 \mu \mathrm{g}$ prolactin $\mathrm{ml}^{-1}(n=19$ embryos $)$ and $\mathrm{E}$, $\mathrm{DMEM}+5 \mu \mathrm{g}$ prolactin $\mathrm{ml}^{-1}(n=17$ embryos). For treatments C, D and E, prolactin was added after I day of culture in DMEM alone. Blastocyst attachment to feeder layer and formation of primary ES-like cell colonies were observed at 1 , $3,10,13$ and 18 days of culture. The medium was changed every 2 days.

\section{Establishment of ES-like cell lines}

Mink primary ES-like cell colonies were passed by physically detaching the colonies with a mouth-controlled pipette and washing them through two drops of $\mathrm{Ca}^{2+}$ - and $\mathrm{Mg}^{2+}$-free PBS. After the brief washing, the colony was placed into a small drop $(20-25 \mu \mathrm{l})$ of trypsin-EDTA $(0.25 \%(\mathrm{w} / \mathrm{v})$ trypsin and $0.04 \%(w / v)$ EDTA; Life Technologies) under dimethylpolysiloxane, viscosity 50 centistokes, (Sigma) and digested by incubating to digest for $4-5 \mathrm{~min}$ at $37^{\circ} \mathrm{C}$. Trypsin activity was then neutralized by adding an equal volume $(20-25 \mu \mathrm{l})$ of FBS to the drop. Colonies were disaggregated into small clumps and single cells by repeated aspiration with a 20 to $25 \mu \mathrm{m}$ capillary of a pulled glass Pasteur pipette and then transferred to four-well dishes that were $95-100 \%$ confluent with mouse primary embryonic fibroblast feeder cells. ES-like cells were identified 7 days after mechanical disruption.

\section{Staining of alkaline phosphatase}

The morphological evaluation of mink ES-like cell colonies was confirmed by cytochemical staining of alkaline phosphatase activity. Cell cultures were fixed in $4 \%(\mathrm{v} / \mathrm{v})$ formaldehyde in PBS for 10-15 min. After washing with distilled water, the fixed cultures were incubated for $15-30 \mathrm{~min}$ in distilled water containing $240 \mu \mathrm{g}$ fast blue RR salt $\mathrm{ml}^{-1}$ and $40 \mu \mathrm{l}$ naphthol AS-MX phosphate $\mathrm{ml}^{-1}$ (Sigma) at $\mathrm{pH}$ 8.6. The reaction was terminated by rinsing with PBS. 

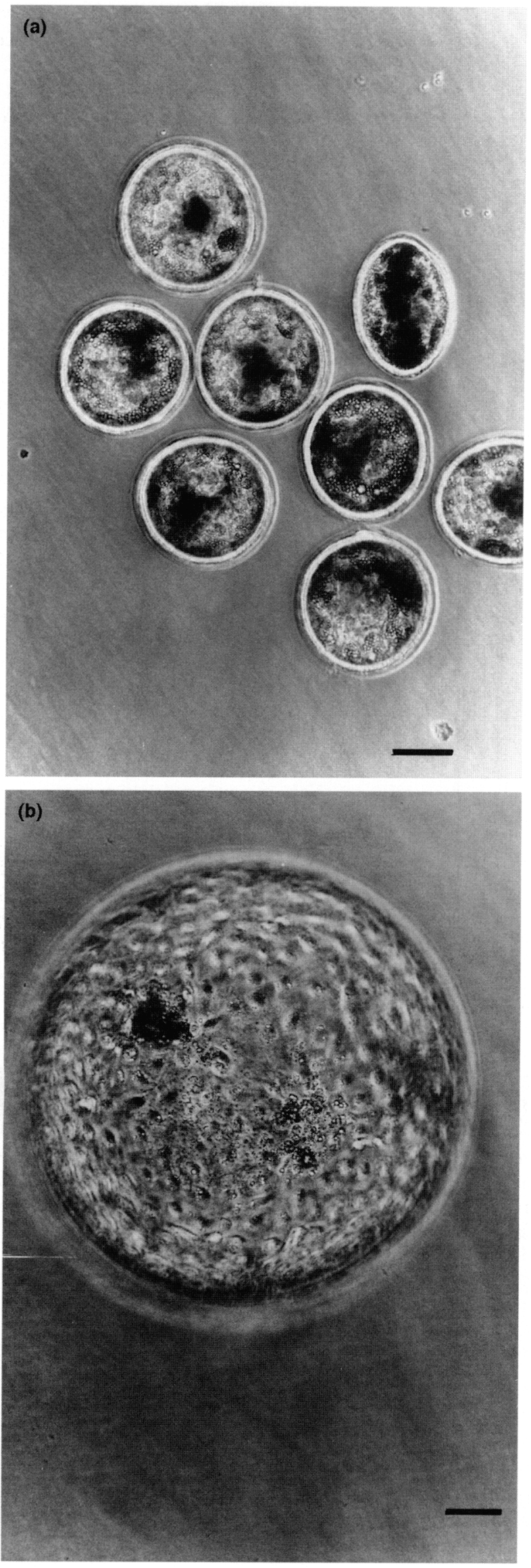

\section{Statistical analyses}

Prolactin reactivation data were first analysed in five treatments by a four time periods model using binomial chi-square analysis (Cochran and Cox, 1957) partitioned by treatment, time and treatment-by-time interaction. If the time-bytreatment in a similar manner interaction was not significant, indicating all embryos responded to treatment in a similar manner over time, the data were further analysed by chi-square within each time period. If found significant, treatment pairs within time period were grouped in $2 \times 2$ contingency tables and tested by chi-square analysis. For the first 10 days of culture, conditions for treatments A and B were identical so the embryos were pooled as treatment $A$ during this period for chi-square analysis. The significance level for all tests was $P<0.05$. Chi-square analysis calculations were performed by Statview Version 4.5 (Abacus Concepts, Berkeley, CA).

\section{Results}

Embryos at various stages of development (eight-cell to early blastocyst) were recovered from the oviduct on day 5 after mating. Early embryos (8-cell, 16-cell and morulae) were transferred into $30 \mu \mathrm{l}$ drops (up to 10 embryos per drop) of CR2 medium and cultured to the blastocyst stage; early blastocysts $(n=9)$ were transferred to DMEM treatment groups. One of nine eight-cell embryos, one of one 16-cell embryo and two of two morulae were developed to blastocysts.

On day 7 and days 13-16 after coitus, blastocysts were flushed from the uterus and transferred to DMEM medium. Most blastocysts collapsed during collection but re-expanded within $24 \mathrm{~h}$ after being placed in culture. Blastocyst diameter averaged $203 \mu \mathrm{m}$ on day 7 (Fig. 1a) and $439 \mu \mathrm{m}$ on days 13-16. Sixty-four per cent of blastocysts placed in culture increased in diameter during the 10 days of culture (Fig. 1b). The diameter of blastocysts following the 10 days of culture ranged from 700 to $1200 \mu \mathrm{m}$.

Only two out of the seven day 13-16 blastocysts maintained in DMEM medium without prolactin (treatment A) attached to the feeder layer within 18 days of culture (Fig. 2a). Most embryos exhibited delayed attachment, which would appear to imitate delayed implantation in vivo. In treatment B, no embryos attached during the first 10 day culture period; however, the addition of $5 \mu \mathrm{g}$ prolactin $\mathrm{ml}^{-1}$ on day 10 induced a marked increase in embryonic attachment within $72 \mathrm{~h}$ of prolactin supplementation (Fig. 2b). No delayed attachment was observed in treatments $C, D$, and $E$, which contained various prolactin concentrations (Fig. $2 \mathrm{c}-\mathrm{e}$ ). After blastocysts had been in culture for 18 days, there was no significant correlation between dose of prolactin and the percentage of blastocysts attaching to mouse primary embryonic fibroblast cells in groups B, C and D $(P<0.05$; Table 1$)$; however, the percentage of ES-like cells established was significantly lower $(P<0.05)$ in group $C$ that had been treated with $10 \mathrm{ng}$

Fig. 1. (a) Mink blastocysts recovered on day 7 after mating. (b) Expanded mink blastocyst after 10 days in culture. Scale bars represent $100 \mu \mathrm{m}$. 

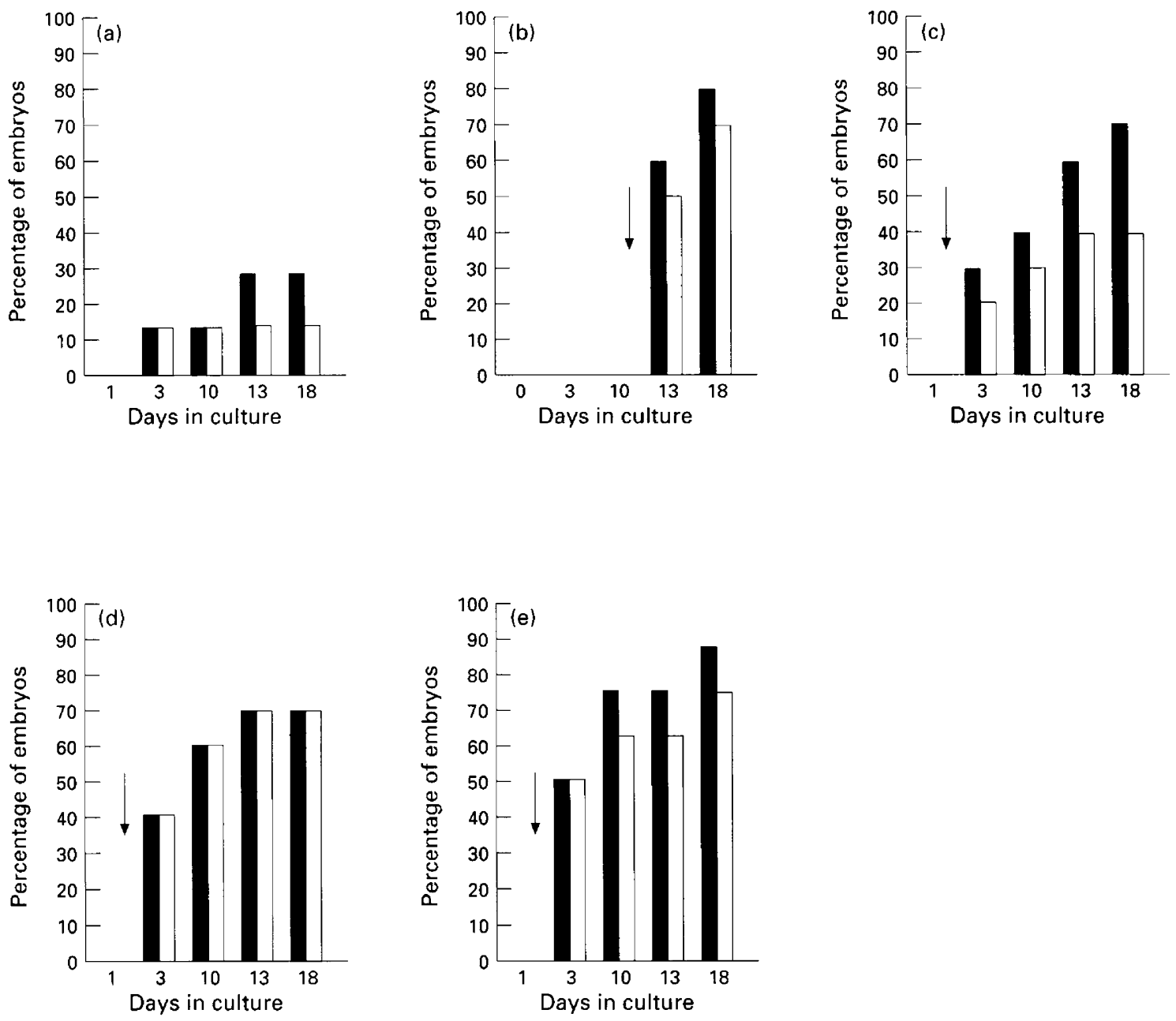

Fig. 2. Effect of prolactin on the attachment and outgrowth of day 13-16 blastocysts ( $\square$ ) and the subsequent isolation of mink embryonic stem cell lines ( $\square$ ). Prolactin was added to media at the time indicated by arrows to the following concentrations: (a) no treatment $(n=16)$; (b) $5 \mu \mathrm{g}$ prolactin $\mathrm{ml}^{-1}$ after 10 days in culture $(n=17)$; (c) $10 \mathrm{ng}^{-1}$ prolactin ml $\mathrm{ml}^{-1}$ $(n=17)$; (d) I $\mu \mathrm{g}$ prolactin $\mathrm{ml}^{-1}(n=19)$ and (e) $5 \mu \mathrm{g}$ prolactin $\mathrm{ml}^{-1}(n=17)$. The ability of prolactin to terminate diapause occurs within 3 days of supplementation and the response appears to be dose responsive. In addition, embryos can be maintained in vitro in prolactin-free medium for 10 days in a state of diapause; after addition of prolactin, a high proportion terminate diapause and form outgrowths (b).

Table 1. Effect of prolactin on the attachment of day 13-16 mink blastocysts

\begin{tabular}{|c|c|c|c|c|}
\hline \multirow[b]{2}{*}{ Treatment } & \multicolumn{4}{|c|}{ Number $(\%)$ of embryos attached } \\
\hline & Day $3^{*}$ & Day $10^{*}$ & Day $13^{*}$ & Day $18^{*}$ \\
\hline $\begin{array}{l}\text { Control } \\
5 \mu \mathrm{g} \text { prolactin } \mathrm{ml}^{-1} \text { after } 10 \text { days }\end{array}$ & $1(14.3)^{\mathrm{a}}$ & $1(14.3)^{\mathrm{a}}$ & $\begin{array}{l}2(28.6)^{\mathrm{a}} \\
6(60.0)^{\mathrm{b}}\end{array}$ & $\begin{array}{l}2(28.6)^{\mathrm{a}} \\
8(80.0)^{\mathrm{bc}}\end{array}$ \\
\hline $10 \mathrm{ng}$ prolactin $\mathrm{ml}^{-1}$ & $3(30.0)^{\mathrm{b}}$ & $4(40.0)^{\mathrm{b}}$ & $6(60.0)^{b}$ & $7(70.0)^{b}$ \\
\hline $1 \mu \mathrm{g}$ prolactin $\mathrm{ml}^{-1}$ & $4(40.0)^{\mathrm{bc}}$ & $6(60.0)^{c}$ & $7(70.0)^{\mathrm{bc}}$ & $7(70.0)^{\mathrm{b}}$ \\
\hline $5 \mu \mathrm{g}$ prolactin $\mathrm{ml}^{-1}$ & $4(50.0)^{c}$ & $6(75.0)^{\mathrm{d}}$ & $6(75.0)^{c}$ & $7(87.5)^{c}$ \\
\hline
\end{tabular}

*Numbers indicate days in culture.

a.b,c,d Values within columns with different superscripts are significantly different $(P<0.05)$

prolactin $\mathrm{ml}^{-1}$ than in the groups treated with either $1 \mu \mathrm{g}$ $\mathrm{ml}^{-1}$ (D) or $5 \mu \mathrm{g} \mathrm{ml}^{-1}$ (B and E) of prolactin (Table 2). The maximum 'implantation' of embryos in vitro and subsequent production of ES-like cells occurred by culturing day 13-16 blastocysts in medium supplemented with $5 \mu \mathrm{g}$ prolactin $\mathrm{ml}^{-1}$. 
Table 2. Effect of prolactin on establishment of mink embryonic stem (ES)-like cell lines

\begin{tabular}{|c|c|c|c|c|}
\hline \multirow[b]{2}{*}{ Treatment } & \multicolumn{4}{|c|}{$\begin{array}{c}\text { Number (\%) of ES lines established from } \\
\text { day } 13-16 \text { attached embryos }\end{array}$} \\
\hline & Day $3^{*}$ & Day $10^{*}$ & Day $13^{*}$ & Day $18^{*}$ \\
\hline $\begin{array}{l}\text { Control } \\
5 \mu \mathrm{g} \text { prolactin } \mathrm{ml}^{-1} \text { after } 10 \text { days }\end{array}$ & $I(14.3)^{\mathrm{a}}$ & $1(14.3)^{\mathrm{a}}$ & $\begin{array}{l}I(14.3)^{\mathrm{a}} \\
5(50.0)^{\mathrm{b}}\end{array}$ & $\begin{array}{l}1(14.3)^{\mathrm{a}} \\
7(70.0)^{\mathrm{c}}\end{array}$ \\
\hline $10 \mathrm{ng}$ prolactin $\mathrm{ml}^{-1}$ & $2(20.0)^{\mathrm{a}}$ & $3(30.0)^{b}$ & $4(40.0)^{b}$ & $4(40.0)^{b}$ \\
\hline $1 \mu \mathrm{g}$ prolactin $\mathrm{ml}^{-1}$ & $4(40.0)^{b}$ & $6(60.0)^{c}$ & $7(70.0)^{c}$ & $7(70.0)^{c}$ \\
\hline $5 \mu \mathrm{g}$ prolactin $\mathrm{ml}^{-\mathrm{I}}$ & $4(50.0)^{b}$ & $5(62.5)^{\mathrm{c}}$ & $5(62.5)^{\text {bc }}$ & $6(75.0)^{c}$ \\
\hline
\end{tabular}

* Numbers indicate days in culture.

${ }_{a . b . c . d}$ Values within columns with different superscripts are significantly different $(P<0.05)$.

Binomial chi-squared analysis of embryo attachment to feeder cells of the embryos that were in diapause at the time they were removed from the uterus revealed significant differences for treatment and time but no significant difference for the treatment-by-time interaction. Within-time comparisons were significant and therefore allowed pairwise comparisons of prolactin concentrations within times.

Exposure to prolactin concentrations from $1 \mu \mathrm{g} \mathrm{ml} \mathrm{m}^{-1}$ to $5 \mu \mathrm{g} \mathrm{ml}^{-1}$ for as few as 3 days significantly increased the number of embryos attaching to feeder cells. Approximately $50 \%$ of embryos that attached during the 18 days in culture had attached by day 3 of culture. There was also a significant increase in attachment with increasing dose of prolactin by day 3 that held for the full 18 days of culture. In addition, diapause embryos cultured for the first 10 days without prolactin, then with $5 \mu \mathrm{g}$ prolactin $\mathrm{ml}^{-1}$, had the same rate of attachment after 3 days exposure to the hormone as did diapause embryos newly removed from donors and cultured for 3 days in $5 \mu \mathrm{g}$ prolactin $\mathrm{ml}^{-1}$ (Table I). A similar comparison at 10 days exposure to prolactin also demonstrated no significant difference (Table 1).

No delayed attachment was observed from embryos recovered during the first week after mating. Five of nine embryos $(55.5 \%)$ attached and started to proliferate (Fig. 3a) during 18 days in culture. There were embryos that attached to feeder cells and established embryonic stem-like cell colonies in all treatment groups. No influence of prolactin was observed for attachment rates when $5 \mu \mathrm{g}$ prolactin $\mathrm{ml}^{-1}$ was added on day 10 (Fig. 3b). The percentage of blastocysts attaching did not differ significantly among groups $B\left(5 \mu \mathrm{g} \mathrm{ml}^{-1}\right.$ prolactin after 10 days in culture), $C\left(10 \mathrm{ng}\right.$ prolactin $\left.\mathrm{ml}^{-1}\right)$ and $\mathrm{D}(1 \mu \mathrm{g}$ prolactin $\mathrm{ml}^{-1}$ ) (Fig. 3b-d). On day 18, the percentage of ES-like cell colonies established from day 7 blastocysts was significantly lower $(P<0.05)$ than the percentage of attached embryos in groups A, B and C (Fig. 3a-c); however, there was no significant difference between the percentage of attached embryos and ES-like cell lines established in groups D and E, which indicates that prolactin at concentrations of $1 \mu \mathrm{g} \mathrm{ml} l^{-1}$ and $5 \mu \mathrm{g} \mathrm{ml}^{-1}$, when added on day I of culture, enhances ES-like cell line establishment (Fig. 3d, e). The same concentrations of prolactin significantly increased establishment of ES-like cell lines from day 13-16 blastocysts not only when prolactin was applied on day 1 , but also when added on day 10 (Fig. 2).
The chi-squared test was used to analyse the embryo reactivation data even though one of the assumptions inherent in its use is that expected values in any category will not be small, often interpreted to mean lower than 5. Owing to the small overall number of embryos available for this study, several categories had expected values lower than five and a few had expected values lower than three. The more conservative Fisher's exact test was also used to analyse data in $2 \times 2$ contingency tables. When this test was applied to the pairwise within-time treatment comparisons, there were no significant differences. For larger tables, some authors have concluded that the rule of 5 is too stringent and that expected values as low as 1 are acceptable (Everitt, 1977). In addition, the application of the more restrictive probability $(P<0.01)$ would not have changed the overall conclusions.

Primary outgrowths were observed within 2-3 days of blastocyst attachment. These outgrowths had an epithelial cell-like morphology and were represented by two types of cells: (I) trophoblast cells ( $35 \mu \mathrm{m}$ in diameter) containing a large granular cytoplasm and (2) small ES-like cells varying in size $(8-12 \mu \mathrm{m}$ in diameter). The nucleus:cytoplasm ratio for trophoblast cells and for ES-like cells was 1:18.79 and 1:1.56, respectively (Fig. 4). The primary ES-like cell morphology outgrowths were disaggregated 8-10 days after their formation and transferred to fresh feeder layers. Fast proliferating colonies were observed 3-5 days after first passage. A total of 42 individual ES-like cell line cultures was established. Ten of these were chosen at random to maintain as cell lines. The cell lines were cultured for up to 8 months without any notable morphological differentiation and samples were frozen from each line after 2 months. During culture, simple embryonic bodies were produced. Mink ES-like cells were induced to differentiate into fibroblast-like and epithelial-like cells when cultured without feeder layers. Several mink embryonic stemlike cell lines established in this experiment were tested by cytochemical staining for alkaline phosphatase activity. ES-like cell lines were alkaline phosphatase positive at the early passages as well as after long-term culture (Fig. 5). Only after cellular differentiation was alkaline phosphatase activity lost.

\section{Discussion}

Embryos that were flushed from the reproductive tract on days 5 and 7 (after the last mating) did not demonstrate delayed 

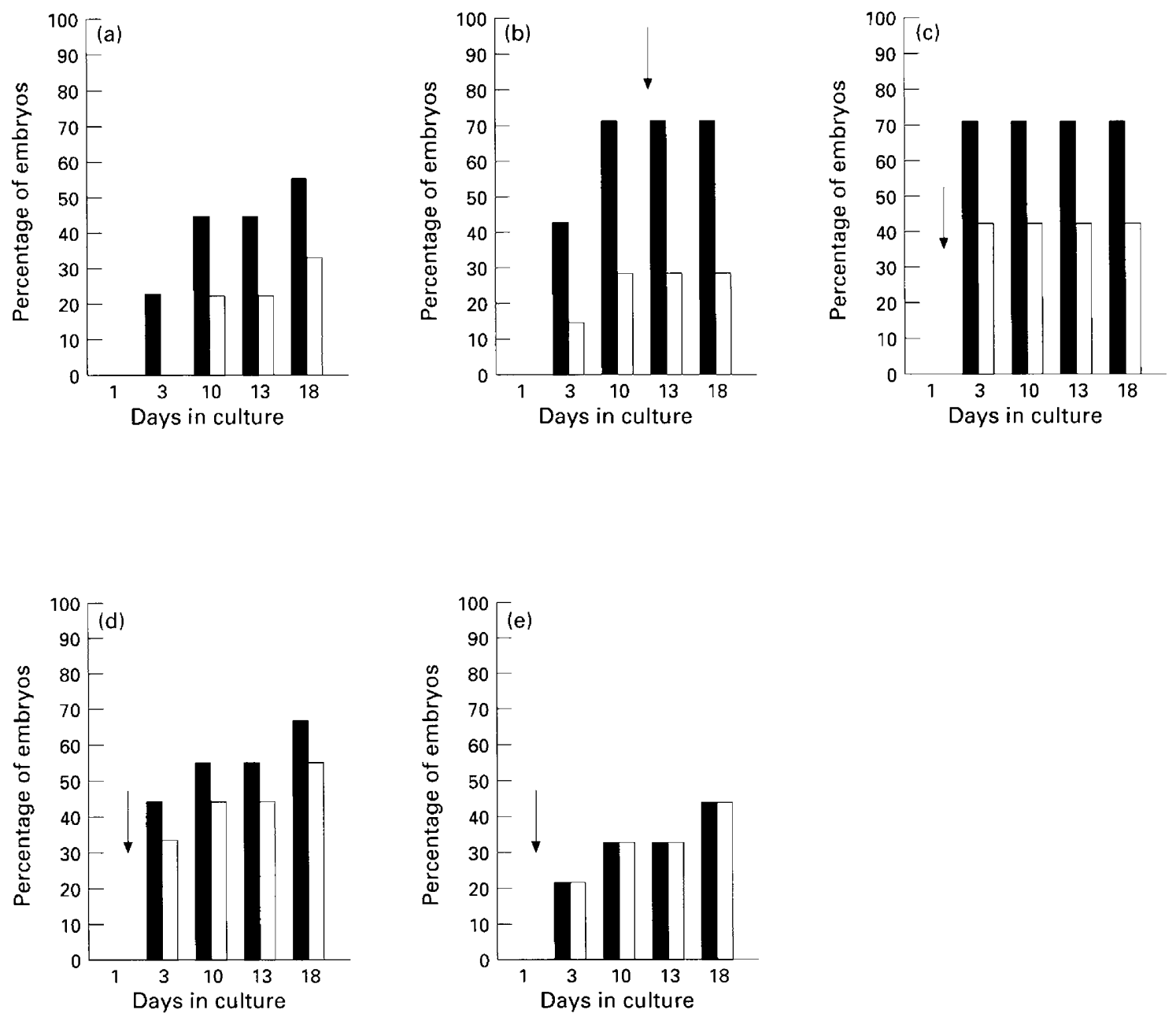

Fig. 3. Effect of prolactin on the attachment and outgrowth of day 7 blastocysts ( $\boldsymbol{\square}$ ) and the subsequent isolation of mink embryonic stem-like cell lines $(\square)$. Prolactin was added to media at the time indicated by arrows to the following

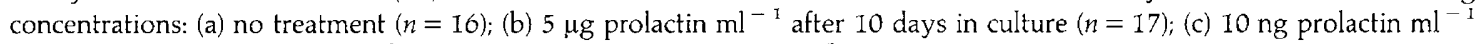
$(n=17)$; (d) $1 \mu$ g prolactin $\mathrm{ml}^{-1}(n=19)$ and (e) $5 \mu \mathrm{g}$ prolactin $\mathrm{ml}^{-1}(n=17)$. Day 7 blastocysts failed to exhibit the same proportion of diapause as that observed in day 13-16 blastocysts.

'implantation' in vitro; whereas the majority of blastocysts recovered on days 13-16 remained in a morphological state resembling diapause. Therefore, the uterine environment and not embryonic genetic programming may be inducing delayed implantation in mink. Prolactin acts directly on diapause blastocysts to reactivate them in vitro.

Martinet et al. (1981) demonstrated that plasma prolactin concentrations increased consistently from 4 to $24 \mathrm{ng} \mathrm{ml}^{-1}$ between day 3 and days 38-48 of pregnancy and that prolactin concentration averaged $10 \mathrm{ng} \mathrm{ml} \mathrm{m}^{-1}$ at the time of implantation. In the study reported here, $10 \mathrm{ng}$ prolactin $\mathrm{ml}^{-1}$ was effective in ending diapause, but higher concentrations resulted in a higher proportion of blastocysts forming ES-like cell colonies.

Most attempts to culture mink embryos have been unsuccessful. Daniel $(1967,1970)$ reported that embryos failed to survive beyond $24 \mathrm{~h}$, in spite of the use of complex culture media. However, the coculture of mink embryos within obligate diapause with Buffalo rat liver (BRL) cells, epithelial cells, stromal cells, or the combination of stromal and epithelial cells, increases the length and frequency of survival (Moreau et al., 1995). The percentages of cocultured embryos that survived for $72 \mathrm{~h}$ or more were $93 \%, 65 \%, 75 \%$ and $68 \%$, respectively. In our study, mouse primary embryonic fibroblasts were effective in maintaining blastocysts within obligate diapause. Ninety-four per cent of embryos survived for $72 \mathrm{~h}$ or more in culture.

Low efficiency of isolation of mink ES cells has been reported by Sukoyan et al. (1992). Only three ES-like cell lines were obtained from 28 embryos when mouse primary embryonic fibroblasts were used as feeder cells. Our protocol for culturing preimplantation mink embryos resulted in up to $75 \%$ mink ES-like cell line establishment.

Cytochemical staining for alkaline phosphatase activity of mink ES-like cells was positive during short- and long-term culture. Induced differentiation by culturing ES-like cells without a feeder layer resulted in the alkaline phosphatase signal being lost. Positive alkaline phosphatase staining of mink ES-like cells is similar to observations made in mice (Wobus et al., 1984) and rats (Iannaccone et al., 1994). Positive alkaline 


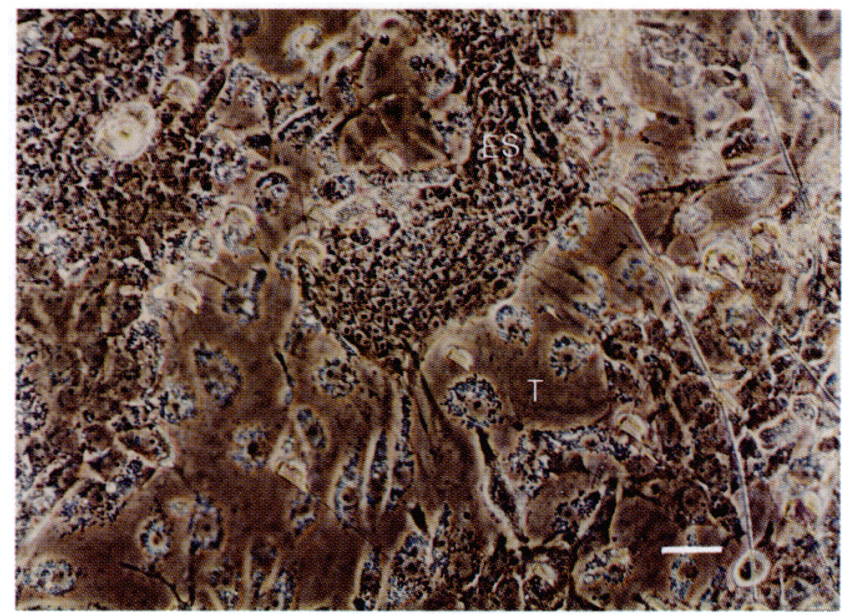

Fig. 4. Mink primary blastocyst-derived colony represented by two types of cells: trophoblast (T) cells containing large granular cytoplasm and small embryonic stem (ES)-like cells with a high nucleus: cytoplasm ratio. These types of cells were observed immediately after blastocyst attachment. The attached blastocyst spread into a monolayer and the cell populations were represented by the two cell types. Sukoyan et al. (1993) described the same types of cells. Only ES-like cells were used for subsequent passages and ES-like cell morphology was maintained in long term cultures (240 days in culture, passage 34 ). Scale bar represents $50 \mu \mathrm{m}$.

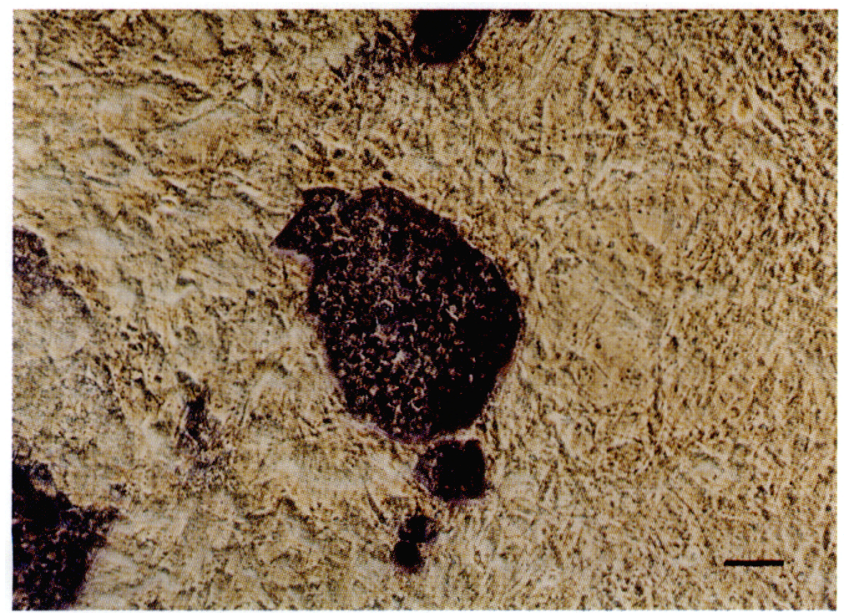

Fig. 5. Fast Blue-napthol AS-MX staining of mink embryonic stem (ES)-like cell colonies (112 days in culture, passage 18) maintained on a mouse primary embryonic fibroblast feeder layer. Embryonic stemlike colonies were stained for alkaline phosphatase activity at three sampling times: first, after 22 days in culture, passage 3; second, after 112 days in culture, passage 18; and third, after 240 days in culture, passage 34. All mink ES-like cells were positive for alkaline phosphatase activity at all sampling times. Scale bar represents $100 \mu \mathrm{m}$.

phosphatase staining of pig and sheep epiblast cells has also been reported by Talbot et al. (1993), who stated that the successful culture of ES-like cells in pig and sheep results in alkaline phosphatase positive cells. The alkaline phosphatase staining technique is fast and simple and requires only the naphthol AS-MX substrate in combination with trapping diazonium salts. Thus, alkaline phosphatase activity is a very convenient marker for confirming the morphological identification of mink ES-like cells.

The results reported here indicate that mink embryos require an exposure time of $>7$ days in the reproductive tract to induce diapause. Prolactin appears to act directly on embryonic cells to terminate diapause and should be supplemented to media to facilitate the establishment of ES-like cell lines. Although it is possible that the prolactin effect may be mediated by the feeder cells, to our knowledge, no such effect on mouse primary embryonic fibroblast feeder cells has been reported. Finally, alkaline phosphatase may be a convenient marker to confirm the presence of ES-like cells in culture

The authors thank D. V. Sisson for advise in statistical analysis and M. E. Aston for valuable technical assistance. This work was partially supported by the Utah Department of Economic Development COEP 95-43708. Published as Utah Experiment Station Journal Article 4928.

\section{References}

Benham FJ, Andrews PW, Knowles BB, Bromson DL and Harris HO (1984) Alkaline phosphatase isozymes as possible marker of differentiation in human testicular teratocarcinoma cell lines Developmental Biology $88279-$ 287

Bloom ME, Race RE and Wolfinbarger JB (1980) Characterisation of Aleutian disease virus as a parvovirus Journal of Virology 35 836-843

Cochran WAG and Cox GM (1957) Statistical analysis with data arranged in two classes In Experimental Designs pp 103-106. John Wiley \& Sons, New York

Daniel JC (1967) Studies on growth of the mink blastocyst foumal of Embryology and Experimiental Morphology 17 293-302

Daniel JC (1970) Dormant embryos of mammals Bioscience 2041 I-415

Everitt BS (1977) $\mathrm{r} \times \mathrm{c}$ Contingency tables. In The Analysis of Contingency Tables p 40. Chapman and Hall, Ltd, London

Hansson A (1947) The physiology of reproduction in mink Mustela vison Schreb.) with special reference to delayed implantation Acto Zoology Stockholmi $\mathbf{2 8} 1-136$

Hartsough GR and Gorham JR (1956) Aleutian disease in mink Notional Fur News 28 10-II

lannaccone PM, Taborn GU, Garton RL, Caplice MD and Brenin DR (1994) Pluripotent embryonic stem cells from rat are capable of producing chimeras Develoumental Biology $163288-292$

Johnson LV, Calarco PG and Siebert ML (1977) Alkaline phosphatase activity in the preimplantation mouse embryo Journal of Enlowyology and Experimental Morphology $4083-89$

Koller BH and Smithies $\mathrm{O}$ (1992) Altering genes in animals by gene targeting Antutal Revicie of Immmology $10705-730$

Koopman P and Cotton RGH (I984) A factor produced by feeder cells which inhibits embryonal carcinoma cell differentiation Experinental Cell Research $154233-2+2$

Martinet L, Allais C and Allain D (1981) The role of prolactin and LH in luteal function and blastocyst growth in mink (Mustela vison) Joumal of Reprodticfion and Fertility Suplement 29 I 19-130

Moreau GM, Arslan A, Douglas DA, Song J, Smith LC and Murphy BD (1995) Development of immortalized endometrial epithelial and stromal cell lines from the mink (Mustelin vison) uterus and their effects on the survival in vitro of mink blastocysts in obligate diapause Biology of Reproduction 53 5 I $1-5] 8$

Muller M and Brem G (1991) Disease resistance in farm animals Experientia 47 923-934

Murphy BD and James DA (1974) Effect of light and sympathetic innervation to the heat on gestation in mink Joumal of Experimentul Zoology $187267-276$

Nicolas JF, Anver P, Gaillard J, Guenet JL and Jacob F (1976) Cell lines derived from teratocarcinomas Cancer Resench $364224-4231$ 
Papke RL, Concannon P, Travis HF and Hansel W (1980) Control of luteal function and implantation in the mink by prolactin Journal of Animal Science 50 1102-1107

Pease S, Braghetta P, Gearing D, Grail D and Williams RL (1990) Isolation of embryonic stem (ES) cells in media supplemented with recombinant leukemia inhibitory factor (LIF) Developmental Biology 141 344-352

Polejaeva IA, White KL, Reed WA and Ellis LC ( 1995) Isolation and long-term culture of mink and bovine embryonic-like cells Theriogenology 43300

Sukoyan MN, Golubitza AN, Zhelezova AI, Shilov AG, Valotin SY, Maximovsky LF, Andreeva LE, McWhir J, Pack SD, Bayborodin SI, Kerkis AY, Kizilova HI and Serov OL (1992) Isolation and cultivation of blastocyst-derived stem cell lines from American mink (Mustela vison) Molecular Reproduction and Development 33 418-431

Sukoyan MN, Valotin SY, Golubitza AN, Zhelezova AI, Semenova LA and Serov OL (1993) Embryonic stem cells derived from morulae, inner cell mass, and blastocysts of mink: comparisons of their pluripotencies Molecular Reproduction and Development 36 148-158
Talbot NC, Rexroad CE, Pursel VG and Powell AM (1993) Alkaline phosphatase staining of pig and sheep epiblast cells in culture Molecular Reproduction and Development 36 139-147

Wheeler MB, Rund LA and Bleck GT (1995) The use of embryonic stem cells in the production of transgenic livestock Embryo Transfer Newsletter 13 20-25

Wilkinson RF, Ming R, Anderson B, Bunch TD and White KL (1996) The use of neural networks in developing novel embryo culture media-formulations Theriogenology 45 41-49

Wilmut I, Hooper ML and Simons JP (1991) Genetic manipulation of mammals and its application in reproductive biology Journal of Reproduction and Fertility 92 245-279

Wobus AM, Holzhauser H, Jakel N and Schoneich J (1984) Characterization of a pluripotent stem cell line derived from a mouse embryo Experimental Cell Research 152 212-219

Zhou X, Sasaki H, Lowe L, Hogan BLM and Kuehn M (1993) Nodal is a novel TGF-b-like gene expressed in the mouse node during gastrulation Nature 361 543-547 